\title{
Landscape ecological and visual significance of dendrological gardens in the Carpathian Basin
}

\author{
Albert FEKETE, ${ }^{1 *}$ Máté SÁROSPATAKI, ${ }^{1}$ Katalin TAKÁCS ${ }^{1}$ \\ ${ }^{1}$ Corvinus University of Budapest, Faculty of Landscape Architecture \\ H-1118 Budapest, Villányi út 29-43.email: albert.fekete@uni-corvinus.hu, (*corresponding author), \\ mate.sarospataki@uni-corvinus.hu,katalin.takacs@uni-corvinus.hu
}

Manuscript received 20. 08. 2014; revised 11. 09. 2014; accepted 14. 09. 2014

\begin{abstract}
This article presents and summarizes our observations based on historical research and site visits of 130 dendrological gardens in Hungary and 36 sites in Transylvania. The results favourably demonstrate the outstanding ecological and landscape values of these dendrological gardens in the Carpathian Basin. The research identifies the most typical exotic woody species that can be still found in those dendrological gardens that were developed in the Carpathian Basin during the era of creating landscape gardens, which is the $19^{\text {th }}$ century in our region. We have defined about twenty exotic tree species, located in the researched dendrological gardens, of which presence highly affects the architectural and botanical composition, just as the landscape appearance or atmosphere of these gardens. Beyond all these effects, the article also highlights two other important points of the dendrological gardens: firstly, these gardens were breeding and acclimatization centres for spreading the new woody species, while, on the other hand, representatives of the spontaneous flora remained as veteran trees in these protected gardens, representing - mainly due to their age - outstanding ecological, dendrological and cultural values.
\end{abstract}

Keywords: landscape ecology, historical garden, dendrological garden, exotic tree, arboretum, Carpathian Basin, Transylvania

\section{Introduction}

In the course of landscape historical and horticultural history researches, the plant use of past ages is an important factor in the analysis of environmental interactions, i.e. the connection of humans and the landscape proper. The knowledge of this factor is indispensable not only for cultural history, but it also facilitates a better understanding of contemporary land use and future landscape 
ecological planning. Archaeobotanical investigations have a special significance in this respect. This discipline is focusing on the relation of mankind and the flora, providing an aspect of economic activity of past societies. Macrofossils recovered from archaeological excavations are especially valuable when we have no other evidence, written or iconographical, on the agricultural production. The Carpathian Basin is an ancestral home for one of the oldest cultures in Europe. Agricultural production looks back to a past of eight hundred years, the cultivation of vegetables is proven for more than five thousand years, while fruit production has a past of two thousand years in this region [1]. Cereals were introduced in the Neolithic period, leguminous plants mainly in the Bronze Age, while fruits and grape were acclimatized by the mediation of the Romans. These basic features were completed by the specific knowledge about crop plants of Eastern origins from the conquering Hungarians and later on, after conversion to Christianity, various crops of Western origin were naturalized together with their specific production technologies. Among the climatic and ecological features of the Carpathian Basin, the cultivated plants - introduced during centuries of cultivation and the inherent popular selection - complemented the naturally versatile vegetation and resulted in a high degree of biodiversity. According to our data on the development of the dendroflora, the beginning of the Neolithic period in the Carpathian Basin coincided with the beginning of the Atlantic climatic phase, i.e. a warm, humid and temperate climate of sub-Mediterranean character, started approx. 8,000 years ago. This phase brought about the formation of mixed oak forests dominated by oak, elm, linden and ash, and in the shrub level, hazelnut [2].

As a result of climatic changes, among the main species constituting the forests, the ratio of oak showed alternating and complementary tendencies in the Carpathian Basin. In the past thousand years, we consider the climatic deterioration period between the beginning of the $13^{\text {th }}$ century and approx. 1450 , the so-called 'little Ice Age,' as a significant change with essential influence on plant cultivation with obvious effects in the Carpathian Basin as well. Following the general amelioration of the climate, starting in the second half of the $15^{\text {th }}$ century and peaking at the middle of the $16^{\text {th }}$ century, another cool and wet period started with hard and cold winters. From the beginning of the $18^{\text {th }}$ century, another general warming took place, influencing the climate and vegetation of the Carpathian Basin [3]. In this period, the large-scale planting of Robinia pseudoacacia, commonly known as the black locust, was started which is still the only arboreal species planted en masse in the Hungarian villages, apart from the fruit trees [4].

As opposed to this, in the Baroque gardens of the aristocracy, appearing in the Carpathian Basin in the first half of the $18^{\text {th }}$ century, besides fruit trees and the native small-leaved linden (Tilia cordata), the plantation of some alien, exotic arboreal species was started to make use of - predominantly in the form of allées and raster-type plantations (quincunx) - the characteristics of the Baroque spatial 
organization. Moreover - although in the iconographical sources and ground-plans of the Baroque gardens, the arboreal species are typically depicted only as formal elements (allées, bosquets, etc.), without actually mentioning specific plant species -, the use of horse chestnut (Aesculus hippocastanum) is documented in the written sources $[5,6]{ }^{1}$

In this respect, we can mention the garden of the Fáy-Ocskay Castle from Dédács (today, Piski-arboretum, Simeria, RO), mentioned by Zsuzsanna Ocskay in 1954. In a manuscript dated 1763, unfortunately lost in the socialization process in 1949 , a horse chestnut alley is specifically mentioned, leading from the springs of the garden to the centre of the garden (Coanda et al. 2006). ${ }^{2}$ Similarly, exotic plants are mentioned from the same period by Anton Huber (1757) from the KárolyiCastle of Nagykároly, (Carei, RO), mentioning an extended and valuable park with various flowering species and exotic arboreal species [7]. ${ }^{3}$

The 'planted dendroflora' of the Carpathian Basin started to unfold in the second half of the $18^{\text {th }}$ century with the appearance of the Hungarian landscape gardens and became generally widespread during the $19^{\text {th }}$ century with the appearance of arboreta and dendrological gardens as an important factor in landscape and landscape ecology. Typically, the aristocratic gardens represented certain, artificially formed, biotopes, where the conscious plantation of arboreal plants - often collected in a systematic (scientific) aspect - could become an important factor on the landscape-architectural level [8]. ${ }^{4}$

As Attila Szabó T. mentioned, a castle garden was not a simple ornamental garden but rather an intrinsic part of the complex, cultural-historical, ecological and economic (estate) system. It is exactly due to this that the garden was operable and

${ }^{1}$ Gyenis A. (1941): Régi magyar jezsuita rendházak, Budapest, qtd. in: Fatsar K. (2008): Magyarországi barokk kertmúvészet. Budapest, p. 78.

2 „Pe baza unui manuscris din anul 1763 (pierdut în anul naţionalizării - 1949), Suzana Ocskay menționează existența, în perioada respectiva, a unei alei de Aesculus hippocastanum L. de la izvoare (parcela 13) către centrul parcului (alee dispărută între timp).” In: Corina Coanda, Radu, S. (2006): Arboretumul Simeria, monografie, București, 173, 21.

3 Qtd. in: Fekete A. (2012): Az erdélyi kertmüvészet - Maros menti kastélykertek, Kolozsvár, 120, 51.

${ }^{4}$ One of the contemporary descriptions of the botanical garden in Kolozsvár (Cluj-Napoca, RO) - a 14-acre site developed in the 1870s around the summer residence of the Mikó family after being donated to the Transylvanian Museum Society (Erdélyi Múzeum Egyesület) - emphasizes that the "nature-like arranged arboretum fruticum also increases the landscape beauty of the small botanical garden."

In: Richter A. (1905): A Kolozsvári Magyar Királyi „Ferencz József” Tudomány-Egyetem Növénytani Intézete és Botanikus Kertje, Kolozsvár, 78. 
sustainable. Thus, we are studying an ecological-technical system with significant historic and artistic content, which can only be interpreted in its entirety [9]. ${ }^{5}$

The aftertaste of the Baroque style and the expansion of the notion of landscape gardens resulted in the introduction of new tree species in the aristocratic gardens that had been formerly unknown within the Carpathian Basin. Whereas arboreta and dendrological collective gardens were formed in the $19^{\text {th }}$ century and reached their flourishing period in the second half of the century, some of the early landscape gardens were adorned with specific exotic plants planted in an artistic arrangement. The use of white ash (Fraxinus americana), weeping willow (Salix babylonica), common hackberry (Celtis occidentalis), red juniper (Juniperius virginiana), balsam poplar (Populus balsamifera), horse chestnut (Aesculus hippocastanum), staghorn sumac (Rhus typhina) and stone pine (Pinus pinea) mentioned in the garden of Hédervár also proves the early use of exotic tree species $[10,11]{ }^{6}$ The reference on horse chestnut is a good example on how the consistent use of a typical species used in Baroque gardens survives and remains popular in the early landscape gardens, mainly in the form of allées and groups of trees.

In the first half of the $19^{\text {th }}$ century, Palatine Joseph and his son, Archduke Joseph (Hapsburg), planted about 320 species in the Alcsút Arboretum that had been formerly unknown in Hungary [12]. The picturesque array of the plants was curated by landscape architect Károly Tost who also attained everlasting merits as the first gardener of the Margaret Island.

In dendrological gardens, as a variant of landscape gardens, the notion of using the natural beauty of plant specimens as main decoration aspect was prevailing throughout the $19^{\text {th }}$ century. Trees were consequently not only symbols of human emotions, much rather, the expression of their own beauty. Planting exotic species attained wide popularity and plant individuals formerly counted as rare sensations became widespread in the Hungarian dendrological gardens. In the second half of the $19^{\text {th }}$ century, several public parks founded in the region used exotic arboreal species in large numbers, attaining, apart from their role in spatial composition, a decisive role in landscape and settlement architecture as well as settlement ecology. Such an example is the Orczy-garden in Pest, where Bernhard Petri used Robinia pseudoacacia for the plantation of the city's public park for stabilizing aeolian sand (Zádor, 1988). Various exotic species were used in the second half of the $19^{\text {th }}$ century, among others, in the ornamental gardens of

\footnotetext{
${ }^{5}$ Qtd. in: Fekete A. (2007): Transylvanian garden art - Castle gardens along the Maros River, Kolozsvár

${ }^{6}$ Petri [Petri, Bernhard]: Beschreibung des Naturgartens des Herrn Grasen von Wizan zu Hedervar, auf der Insel Schütte in Ungarn. In: Becker, Wilhelm Gottlieb: Taschenbuch für Garten Freunde. Leipzig, 1798, 83.
} 
Pozsony (Bratislava), in the City Park (Városliget) and the Margaret Island in Pest as well as numerous other Hungarian locations $[13,14,15]$.

The appearance and overall distribution of arboreta and dendrological gardens in England and in Europe can also be connected to the popularity of evergreens. "David Douglas has discovered a lot of beautiful American pines and they could show their beauty soon in acclimatisation gardens. [...] striving at planting and naturalise groups of exotic pine trees were common. By this practice, one by one, the beautiful foreign pines started their conquest on the Continent as well." [16]. The fashion of evergreens was soon manifested in the Hungarian dendrological gardens as well. At the beginning of the $19^{\text {th }}$ century, the irregular collective garden of the agricultural school Georgikon at Keszthely, apart from a variety of exotic deciduous tree species, was also ornated by several foreign pine types and served as a living study material for the students. At the same time, the plant groups of the garden - which were systematically registered in sections - served as living materials for the students, as well as decoration for the immediately connected park of the Festetics Castle.

The most important evergreen tree species of the plant list dated 1808 are: Cupressus sempervirens, Ginkgo biloba, Picea mariana, Pinus strobus, Taxodium distichum and Tsuga canadensis (MNL). ${ }^{7}$ The Erdődy Castle Park at Vép had a leading role in the acclimatization of the pine varieties, possessing a considerable collection of evergreens by the $1850 \mathrm{~s}$. In the sixties-seventies of the $19^{\text {th }}$ century at Nagycenk, Bogát (today: Szombathely-Szentkirály), Rátót and Nádasdladány, the Vép model was successfully followed, enriching the former local collections by valuable evergreen species. Rare variants of pine trees were to be found at Vácrátót and Gyöngyösapáti (today: Gencsapáti); the most striking example in this respect was Kámon, where István Saághy created the valuable pine collection of the Öregpark, forming the core of the current Arboretum. Botanical exchange connections are well known and documented among the aristocratic families. It was not by a mere chance that in Malonya (today: Mlyňany, SK) Garden of István Ambrózy-Migazzi, son of Countess Agáta Erdődy, we can find an exceptional collection of evergreens in landscape array, from the beginning of the 1890s till modern times [17]. The landscape-ecological and landscape-aesthetical aspects of the exotic arboreal species in the afore-mentioned garden are adequately reflected in the report of Gusztáv Moesz on Malonya Park [18]: "He [Ambrózy-Migazzi István] did not consider important the number of species in the garden, much rather the abundance of species and forms already established positively. The eyepleasing effect was achieved by the masses of the used species. He did not want to construct a botanical garden but a pleasure garden of Mediterranean character. Plants were only tools in his hands to form and colour the landscape."... Moesz

${ }^{7}$ MNL OL P 275. 356. XIV. No. 58-67. (Hungarian National Archives). 
noted: "I have been many times in Malonya Park. I have always been impressed by the knowledge transformed into art, by the help of which the Count could harmoniously insert the 50 acres of his park into the beautiful landscape of the Zsitva Valley bordered by distant mountains."

The survey of the proprietor families is also important as they carry that conceptual and cultural background, which is essential for the formation of the genius loci and the identity of the site, as well as for the creation of the residence gardens. In several cases, the proprietors shaped or directly influenced the formation of the gardens according to their own ideas.

The owners of noble residences and gardens can be considered as landscape architects, as on several occasions they constructed and cultivated their own gardens, or even if they employed a gardener or an estate manager, they provided the ideas for development.

The main objectives of the current research are to determine the landscapeecological and landscape-architectural factors that have been present till our days. Most probably, these aspects were appearing as a result of the creation of a large number of dendrological gardens constructed in the $19^{\text {th }}$ century.

\section{Material and methods}

The following theoretical work plan was established for the methodical exploration of the dendrological garden remains: preparation of the list of all possible sites, identification of research priority sites, conducting the historic exploration, condition survey and assessment of these priority sites and compilation of their assessment documentation.

\section{Preparation of a list of possible dendrological garden sites}

Recently, data on existing dendrological gardens have been collected in a database for numerical evaluation. The selection of possible research locations was based on former garden history research reflected in technical literature.

The Central European Historic Garden Database (CEHGD; in Hungarian: Történeti Kertek Adattára) was used, which contains the most complete list on the historical gardens of the Carpathian Basin, enumerating more than 1,500 historic or historically significant gardens. Following the database, we can delimit the gardens to be surveyed personally to a reasonable number filtering on potential dendrological gardens.

Historical research

The remains must and can only be interpreted together with the surrounding settlement and site for the full comprehension of their former significance and 
current ecological value. According to this, the historical overview compiled based on archival and literary resources tries to give an accurate picture about the formation and development of the researched gardens. It deals with the garden's determining role in the creation of site character and settlement structure and investigates all those site-scale relationships which were considered as particularities during the creation of the castle garden, and which largely influenced the image of the small region that made up the castle's greater environment especially the existence of characteristic or newly introduced tree species of that epoch. Evidently, the research pays close attention to family historical data, as in many cases they can be directly tied to the formation or remaking of the park, garden parts or elements.

\section{Field survey}

Part of the gardens was irrelevant for the present study: either having no landscape aspect, or having limited dendrological value, or it was of very recent establishment, or it has already perished to an extent that prevents current studies. Accordingly, the most important aspects for the viability of analysis were:

- garden historical value

- photos and documentation reflecting current condition

- vegetation cover or its absence as shown on Google Earth.

The on-site assessment in all cases records the current conditions (drawings, manuals, GPS-coordinates, geodesic surveys, plant assessment, photos etc.) as well as the securable values found so that it could serve as a condition report and comparative basis for any possible future professional use.

Integration of current means and methods of analysis offered a great help in the work, mainly using facilities of the modern IT tools and the Internet. The feasibility of a given area was assessed on the basis of fresh aerial photography and photo images, and text-based descriptions if existing. Aerial photos offered data on vegetation cover and variability of the vegetation in the case of individual castle parks. The current garden descriptions were collected from the official web pages of the communities and institutions maintaining the castles, but we could also use blog-type communications of visitors or recent touristic descriptions or dedicated studies. These pieces of information have frequently allowed locating old and exotic arboreal plant individuals, offering a good argument on the necessity to personally visit the individual parks and gardens.

\section{Results}

The virtual survey delimited our sample set to 130 potential dendrological gardens in Hungary and 36 in Transylvania. On the basis of actual (physical) 
survey, in 90 gardens in Hungary and in 36 gardens in Transylvania, the old exotic tree specimens could still be located. We can define the concept of 'dendrological gardens' accordingly: the spatial composition of the park and the overall atmosphere of the garden are basically determined by exotic arboreal species. In view of the above definition, we could locate 75 dendrological gardens in Hungary and 14 in Transylvania (Fig. 1). ${ }^{8}$

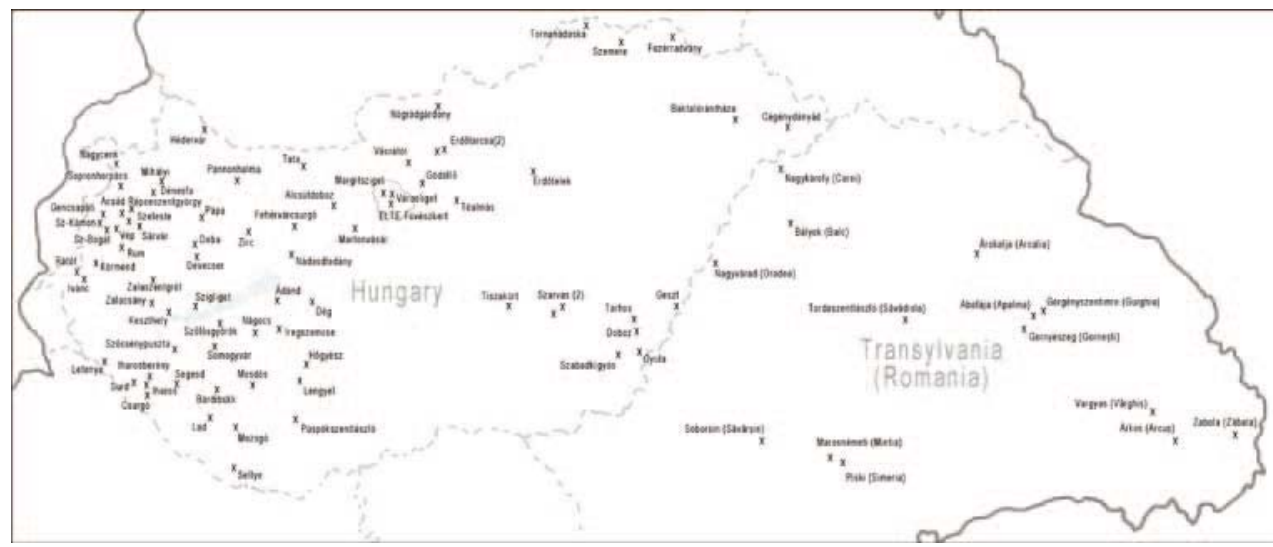

Fig. 1. Geographical disposition of the investigated gardens

It is postulated that the landscape-ecological and landscape-architectural impact of the dendrological gardens of the Carpathian Basin can be primarily attributed to the variable species composition of the investigated gardens $(75+14)$ and the extended application of exotic species.

As a first step of the analysis, the characteristic old exotic specimens determining the current species composition of the gardens, their spatial composition and landscape-architectural impact were identified. The number of such old exotic specimens was altogether 34 in the explored dendrological gardens and all of them were found in at least five different gardens. In the investigated dendrological gardens, 20 arboreal species were located in at least 24 gardens and, among them, 13 arboreal species were found in at least 30 gardens. The most frequently encountered 20 exotic arboreal species, located by field survey, are the following: Platanus $x$ acerifolia, Aesculus hippocastanum, Ginkgo biloba, Fagus sylvatica 'Atropunicea,' Pinus nigra, Liriodendron tulipifera, Sophora japonica, Abies spp., Juglans nigra, Quercus robur f. fastigiata, Magnolia spp., Quercus rubra, Sequoiadendron giganteum, Gymnocladus dioicus, Gleditsia spp., Catalpa

\footnotetext{
${ }^{8}$ The number of dendrological gardens may change in the course of subsequent research with the accumulation of data. Some dendrological gardens are preserved only in the memory of the locals; so, the collection of local lore is absolutely important.
} 
bignonioides, Taxodium distichum, Pinus strobus, Pinus sylvestris, Pseudotsuga menziesii. Table 1 shows the localization of tree species.

Tab. 1. Occurence of tree species

\begin{tabular}{|c|c|c|}
\hline No. & Name of the arboreal species & $\begin{array}{c}\text { Number of } \\
\text { dendrological } \\
\text { gardens } \\
\end{array}$ \\
\hline 1 & Platanus $\mathrm{x}$ acerifolia & 69 \\
\hline 2 & Aesculus hippocastanum & 56 \\
\hline 3 & Pinus nigra & 44 \\
\hline 4 & Ginkgo biloba & 43 \\
\hline 5 & Fagus sylvatica 'Atropunicea' & 41 \\
\hline 6 & Liriodendron spp. & 39 \\
\hline 7 & Sophora japonica & 39 \\
\hline 8 & Abies spp. & 37 \\
\hline 9 & Magnolia spp. & 33 \\
\hline 10 & Quercus robur f. fastigiata & 33 \\
\hline 11 & Quercus rubra & 33 \\
\hline 12 & Juglans nigra & 31 \\
\hline 13 & Gleditsia spp. & 30 \\
\hline 14 & Pinus sylvestris & 28 \\
\hline 15 & Sequoiadendron giganteum & 28 \\
\hline 16 & Catalpa spp. & 27 \\
\hline 17 & Gymnocladus dioicus & 24 \\
\hline 18 & Pinus strobus & 24 \\
\hline 19 & Pseudotsuga menziesii & 24 \\
\hline 20 & Taxodium distichum & 24 \\
\hline
\end{tabular}

Most of the listed arboreal species appeared in the Carpathian Basin during the $19^{\text {th }}$ century (sometimes in the second half of the $18^{\text {th }}$ century) as imported or as a result of local breeding. They were reproducing and spreading successfully in the Hungarian historical gardens. These exotic species withstood the test of time, proved their successful applicability in the (Central) European region; therefore, their further utilization is adequately founded.

The dendrological gardens in the Carpathian Basin, by the help of the numerous exotic arboreal species, essentially contributed to the increase of 
biodiversity, as one of their landscape-ecological merit. In the case of dubious instances, the replacement of the arboreal species - due to its specific environmental demands - should be considered. For the sake of authenticity, however, the replacement should aim at similar aesthetical and landscape-architectural character: exotic or local elements with similar shape, colour, branch system etc.

There are certain instances known when plant species spontaneously growing or eventually planted in the garden proved to be aggressive, oppressing the valuable exotic plants and destroying significant dendrological assemblages.

The landscape-ecological significance of dendrological gardens can be supported by further considerations:

- Dendrological gardens represent a specific segment of green surface facilities, where - due to special status and protection - representatives of local arboreal species of Methuselah's can also be spotted.

We can mention in this respect the following gardens from Hungary: Sárvár, Zsennye, Gencsapáti with centuries-old pedunculate oak forests, the chestnut forest of Szeleste, the beech forest surrounding the garden of Püspökszentlászló. From Transylvania, we can mention Marosvécs (Brâncovenești, RO) with the several centuries-old oak grove and Scots pine (Pinus sylvestris) grove, Bonchida (Bonțida, RO), Kendilóna (Luna de Jos, RO) and Hadad (Hodod, RO) with small-leaved linden and oak, Gernyeszeg (Gorneşti, RO) and Görgényszentimre (Gurghiu, RO) with tall ash trees and the riparian alder forests from Piski (Simeria, RO).

- Dendrological gardens can be considered as a basis for the spread of new species in the past and also in our days. Exotic tree species were imported, as a first step, into these gardens and the surplus of the progeny could be transferred to other nursery gardens, parks, arboreta or the nature proper.

Our survey corroborated a number of contemporary descriptions. We could identify the sycamore trees from Alcsút planted by Palatine Joseph, the ginkgo planted by József Teleki at Gernyeszeg and the gingko trees planted by the Festetics family in the botanical garden of the ELTE University, Budapest. In the park of the Festetics Castle, we could find the almost two-hundred-yearold Ginkgo biloba, presented to the Count by the famous botanist Pál Kitaibel. Moreover, we can still locate the individual specimens of Juglans nigra (unfortunately in dry state) brought to Keszthely by the son of György Festetics, László [19].

- Dendrological gardens were strongholds of Hungarian plant breeding during the $19^{\text {th }}$ and the $20^{\text {th }}$ centuries; therefore, we can consider them as the cradle of new arboreal species and different variants. For example, István Saághy performed considerable scientific activities in respect of pine species, their naturalization, the observation of the limits of their tolerance and their applicability for various purposes. He could select two, formerly unknown 
variants, i.e. Chamaecyparis nootkatensis 'Ericoides' and Picea abies 'Araucarioides'. He also had considerable results in the cross-breeding of pines, crossing for the first time the species Picea glauca and Picea jezoensis in 1917. The new hybrid was named by Gyula Gayer Picea saághy (Saághyspruce) [20]. The Saághy-spruce was located in other Western Hungarian gardens as well; the last specimen died off in the garden of the Sigray Castle at the beginning of the 1990s. The subspecies Thuja occidentalis 'Malonyana' $\mathrm{T}$ was selected by Count István Ambrózi-Migazzi on his Malonya estates [21, 22]. This thuya type of columnar growth can be found recently in several Hungarian dendrological gardens like Kámon or Vép.

- Due to the large number of significant exotic woody plants, frequently planted in mass, the dendrological gardens have remotely striking appearance. By the means of their visual connections remaining to present times, they enrich the landscape character, appearing as spots or characteristic elements in the landscape and represent a serious value to landscape aesthetics.

\section{Discussion and Conclusions}

The comprehensive analysis and systematic researches regarding the ecological significance and landscape values of the dendrological gardens in the Carpathian Basin have not yet been accomplished. The actuality of the topic is supported by the fact that most of the exotic tree species planted in the $19^{\text {th }}$ century have now reached the final stage of their life; therefore, these days are the last option to analyse the dendrological plant material, their ecological effects and the way they had been arranged in a spatial composition.

Our research is trying to fill a gap in historical and ecological garden studies by means of the broadest possible range of field exploration combined with the identification of the dominant tree species influencing the spatial composition and the landscape appearance of the dendrological gardens.

The main value of the dendrological gardens in the $19^{\text {th }}$ century has been manifested by means of the rare plant species. Nowadays, this dendrologic value can be defined by the veteran age and developed habit of the formerly planted and still living woody species, while landscape-ecological and visual values have been formed owing to the acclimatization and wide spreading of the new species.

\section{References}

[1] Gyulai, F. (2000), Klíma, táj, kultúrák: összefüggések és különbözőségek a Kárpátmedencében. In: Füleky, Gy. (ed.), A táj változásai a Kárpát-medencében a történelmi események hatására, Kulturális örökség Igazgatósága, Budapest - Szent István Egyetem, Gödöllő, 9-13. 
[2] Zólyomi, B. (1980), Landwirtschaftliche Kultur und Wandlung der Vegetation im Holozaen am Balaton, Phytocoenologia 7, 121-126.

[3] Rácz, L. (1993), Éghajlati változások a középkori és kora újkori Európában. In: R. Várkonyi, Á., Kósa, L. (eds), Európa híres kertje. Orpheus Könyvkiadó, Budapest, 67-83.

[4] Terpó, A. (2000), A táj szinantropizációja a nagy történelmi sorsfordulók idején. In: Füleky, Gy. (ed.), A táj változásai a Kárpát-medencében a történelmi események hatására, Kulturális örökség Igazgatósága, Budapest - Szent István Egyetem, Gödöllö, 18-25.

[5] Gyenis, A. (1941), Régi magyar jezsuita rendházak. Szalézi Művek, Budapest.

[6] Fatsar, K. (2008), Magyarországi barokk kertmüvészet. Helikon, Budapest.

[7] Fekete, A. (2012), Az erdélyi kertmüvészet - Maros menti kastélykertek. Művelődés, ClujNapoca.

[8] Richter, A. (1905), A Kolozsvári Magyar Királyi „Ferencz József” Tudomány-Egyetem Növénytani Intézete és Botanikus Kertje 1872-1904. Kolozsvár.

[9] Fekete, A. (2007), Transyalvanian garden art - Castle gardens along the Maros River. Mủvelödés Mühely, Cluj-Napoca.

[10] Petri, B. (1798), Beschreibung des Naturgartens des Herrn Grasen von Wizan zu Hedervar, auf der Insel Schütte in Ungarn. In: Becker, W. G., Taschenbuch für Garten Freunde. Voss und Compagnie, Leipzig, 75-93.

[11] Schmidt, G. (ed.) (2003), Kertészeti Dendrológia. BKÁE Kertészettudományi Kar, Budapest.

[12] Andacs, N. (2007), Rejtett értékeink - Mintagazdaságból szépséges angolpark, available at: http://www.geographic.hu (accessed on: 21.06.2007).

[13] Kardos, Á. (1909), Hazai kertek és kertészetek. Kertészeti Lapok 24(1), 4-10.

[14] Hanusz, I. (1890), A budapesti Margitsziget fái. Kertészeti Lapok 5(11), 281-284.

[15] Schmall, L. (1894), A városliget átalakítása. Kertészeti Lapok 9(9), 217-222.

[16] Rapaics, R. (1940), Magyar kertek. Királyi Magyar Egyetemi Nyomda, Budapest.

[17] Mágócsy-Dietz, S., Kovács, J. (eds.) (1935), Az Országos Magyar Kertészeti Egyesület aranykönyve. Globus Nyomdai Müintézet, Budapest.

[18] Moesz, G. (1933), Gróf Ambrózy-Migazzi István dr. Kertészeti Szemle 5(11), 289-292.

[19] Csoma, Zs. (1997), Kertészet és polgárosodás (Az európai szőlészeti-borászati-kertészeti ismeretek oktatása, szaktanácsadása a Georgikonban és a Keszthelyi Uradalomban, a 18. sz. végétől a 19. sz. közepéig). - Centrál-Európa Alapítvány, Budapest.

[20] Mészöly, Gy. (ed.) (1984), Arborétumok országszerte. Mezőgazdasági Kiadó, Budapest.

[21] Orlóci, L. (2005), Örökzöldek és fenyők. Mezőgazda, Budapest.

[22] Józsa, M. (2005), Fenyők. Corvina Kiadó, Budapest. 